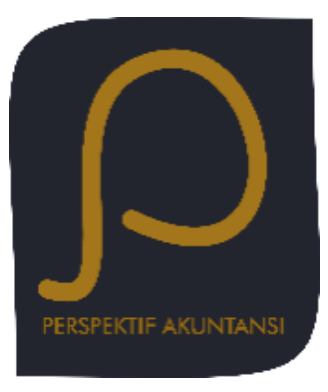

Perspektif Akuntansi

Volume X Nomor X (Agustus 2020), hal. 253-269

ISSN: 2623-0194 (Print), 2623-0186 (Online)

Copyright(C) The Authors(s). All Rights Reserved

Center for Accounting Development and Research (CARD)

Fakultas Ekonomika dan Bisnis,

Universitas Kristen Satya Wacana

DOI: https://doi.org/10.24246/persi.vXiX.p253-269

http://ejournal.uksw.edu/persi

\title{
Pengaruh Pajak Terhadap Kesejahteraan Masyarakat
}

Shandy Jannifer Matitaputty ${ }^{1}$

Universitas Katolik Soegijapranata Semarang

Agung Sugiarto

Universitas Katolik Soegijapranata Semarang

Agnes Arie Mientarry Christy

Universitas Katolik Soegijapranata Semarang

Paulina Rini Hastuti

Universitas Katolik Soegijapranata Semarang

Received Abstract. Tax management is expected to help reduce the poverty rate.

20/08/2020 The feedback of tax payments is indirect so that taxpayers will not receive reciprocity individually but collectively with other residents.

Revised This makes the need for an academic review of the effect of taxes on

20/08/2020 people's welfare. The purpose of this study is to see the effect of taxes on public welfare. The data to be used in this study is secondary data Accepted obtained from the Badan Pusat Statistik Provinsi Jawa Tengah. The 20/08/2020 effect of taxes on welfare is seen through regression analysis. The development of tax revenue from 2010 to 2019 shows a positive trend. The number of poor people has always decreased, even though it is below $5 \%$ per year. The value of per capita income continues to increase with an average growth of $8 \%$ per year. Tax revenue has a relatively strong negative relationship to the number of poor people and has a very strong negative relationship to the percentage of the number of poor people. Tax revenue growth has a negative relationship, which is classified as weak on the growth rate of the number of poor people. Taxes have a positive effect on the per capita income of the population. Tax revenue has a very strong positive relationship to per capita income. The government is advised to increase public tax awareness through socialization or other guidance.

${ }^{1}$ shandy@unika.ac.id 
Keywords: Tax Revenue, Poverty

\begin{abstract}
Abstrak. Pengelolaan pajak diharapkan ikut mengurangi angka kemiskinan suatu negara. Kontraprestasi atas pembayaran pajak bersifat tidak langsung sehingga Wajib Pajak tidak akan mendapatkan timbal balik secara individual melainkan secara kolektif dengan penduduk lainnya. Hal ini menjadikan perlunya tinjauan akademis terkait pengaruh pajak terhadap kesejahteraan masyarakat. Tujuan penelitian ini adalah untuk melihat pengaruh pajak terhadap kesejahteraan masyarakat. Data yang akan digunakan dalam penelitian ini adalah data sekunder yang diperoleh dari Badan Pusat Statistik Provinsi Jawa Tengah. Pengaruh pajak terhadap kesejahteraan dilihat melalui analisa regresi. Perkembangan penerimaan pajak tahun 2010 hingga 2019 menunjukkan tren positif. Jumlah penduduk miskin selalu mengalami penurunan walaupun di bawah 5\% per tahun. Nilai pendapatan per kapita terus mengalami peningkatan dengan rata-rata pertumbuhan $8 \%$ per tahun. Penerimaan pajak memiliki hubungan negatif yang tergolong kuat terhadap jumlah penduduk miskin dan memiliki hubungan negatif yang tergolong sangat kuat terhadap persentase jumlah penduduk miskin. Pertumbuhan penerimaan pajak memiliki memiliki hubungan negatif, yang tergolong lemah terhadap laju pertumbuhan jumlah penduduk miskin. Pajak memiliki pengaruh positif terhadap pendapatan per kapita penduduk. Penerimaan pajak memiliki hubungan positif yang sangat kuat terhadap pendapatan per kapita. Pemerintah disarankan untuk meningkatkan kesadaran pajak masyarakat baik melalui sosialisasi ataupun pembinaan lainnya.
\end{abstract}

Kata kunci : Penerimaan Pajak, Kemiskinan

\title{
Pendahuluan
}

Pajak selama ini dikenal sebagai sumber penerimaan negara terbesar. Indonesia misalnya, sejak tahun 2007 hingga 2019 lebih dari 70 persen penerimaan negaranya berasal dari pajak. Pada tahun 2019, penerimaan pajak negara Indonesia mencapai Rp 1.545,3 Triliun dengan total kontribusi terhadap total penerimaan negara mencapai 78.9\% (www.kemenkeu.go.id). Penerimaan yang begitu besar dari sektor pajak nantinya akan digunakan sebagai sumber pendanaan pembangunan. Sehingga pada akhirnya pajak sebagai diharapkan dapat memberikan manfaat bagi kesejahteraan masyarakat. Hal ini seperti yang dimaksudkan oleh Munawir S. dalam Sulastyawati (2014) bahwa fungsi pajak telah dijalankan dengan baik dapat dilihat melalui indikasi peningkatan kesejahteraan masyarakat yang nampak dengan semakin menurunnya pengangguran, adanya perbaikan fasilitas publik, konsumtifitas masyarakat meningkat, lapangan kerja meningkat, dan banyak anakanak yang dapat menikmati pendidikan. 
Harapan bahwa pajak akan memfasilitasi terciptanya kesejahteraan masyarakat menjadi pendorong bagi masyarakat untuk dengan sukarela menjadi masyarakat yang taat pajak. Penerimaan pemerintah yang sebagian besar berasal dari pajak dikelola dalam APBN untuk sebesar-besarnya kemakmuran rakyat. Salah satu ukuran kemakmuran rakyat adalah pendapatan per kapita mereka. Pendapatan per kapita dihitung dengan turut mempertimbangkan jumlah penduduk sehingga dapat digunakan untuk mengukur pendapatan nasional dan dapat digunakan untuk menggambarkan tingkat kesejahteraan masyarakat. Pendapatan per kapita cukup mewakili hakikat utama pembangunan, yaitu peningkatan kesejahteraan dan penghilangan kemiskinan (Chendrawan, 2017). Masyarakat yang memiliki pendapatan per kapita tinggi diidentifikasi sebagai masyarakat yang makmur. Ukuran lain tingkat kesejahteraan suatu negara adalah rendahnya angka kemiskinan. Pengelolaan pajak diharapkan ikut mengurangi angka kemiskinan suatu negara. Hal ini seperti yang dikatakan oleh Sulastyawati (2014) dalam penelitiannya yang berjudul Hukum Pajak dan Implementasinya Bagi Kesejahteraan Rakyat, bahwa pajak memiliki peran penting dalam mengembangkan kemajuan negara walaupun sampai saat ini sumber penerimaan negara dari pajak masih belum memenuhi kebutuhan dan meningkatkan kesejahteraan masyarakat. Selama ini sumber penerimaan negara yang berasal dari pajak belum maksimal, masih banyak potensi penerimaan pajak yang belum diperhatikan pemerintah. Peran masyarakat juga penting dalam meningkatkan penerimaan pajak. Oleh karena itu diharapkan masyarakat memenuhi kewajibannya sebagai wajib pajak dengan membayar pajak tepat waktu. Dengan demikian kesejahteraan masyarakat diharapkan meningkat (Sulastyawati, 2014).

Kemiskinan merupakan keadaan saat kebutuhan dasar hidup seseorang (pangan, sandang, papan) tidak dapat dipenuhinya. Indonesia menggunakan garis kemiskinan untuk menentukan apakah seseorang tergolong miskin atau tidak miskin. Garis kemiskinan sendiri tersusun atas komponen dasar kebutuhan layak hidup baik makanan maupun non makanan. Penduduk yang memiliki penghasilan di bawah garis kemiskinan disebut dengan penduduk miskin, sementara penduduk yang memiliki penghasilan di atas garis kemiskinan adalah penduduk tidak miskin. Pengelolaan pajak ditujukan untuk peningkatan kemakmuran rakyat termasuk di dalamnya program-program pengentasan kemiskinan. Hal ini seperti yang dikatakan oleh Lisna et al. (2013) dalam penelitiannya yang berjudul Dampak Kapasitas Fiskal terhadap Penurunan Kemiskinan: Suatu Analisis Simulasi Kebijakan, bahwa peningkatan kesejahteraan masyarakat dapat dipengaruhi oleh kebijakan kapasitas fiskal daerah dari sumber utama pajak daerah dan bagi hasil pajak (Lisna et al., 2013).

Di sisi lain masyarakat cenderung malas membayar pajak ketika kurang merasakan manfaat atas pajak yang mereka bayarkan. Hal ini menjadi penyebab seringkali munculnya keraguan apakah pajak benar-benar membawa kesejahteraan bagi masyarakat. Sifat kontraprestasi pajak yang tidak langsung membuat dampak penggunaan pajak menjadi sulit diukur. Hal ini seperti yang dikatakan oleh Fitriah et al., (2019) dalam penelitiannya yang berjudul Faktor-Faktor Psikologis sebagai Determinan Kepatuhan Pajak: Studi Eksplorasi pada Wajib Pajak, bahwa ada 
keraguan besar pada wajib pajak tentang apakah anggaran pajak dikelola dengan benar dan digunakan untuk kesejahteraan umum. Asumsi tersebut yang melatarbelakangi perilaku wajib pajak dalam melaporkan dan membayarkan pajaknya dengan benar (Fitriah et al., 2019).

Kontraprestasi atau timbal balik atas pembayaran pajak bersifat tidak langsung. Hal ini memiliki pengertian Wajib Pajak (WP) tidak akan mendapatkan timbal balik atau kontraprestasi secara individual langsung kepada WP tersebut melainkan secara kolektif dengan penduduk lainnya dalam bentuk-bentuk fasilitas publik maupun bentuk-bentuk belanja negara lainnya. Hal ini menjadikan perlunya tinjauan akademis terkait pengaruh pajak terhadap kesejahteraan masyarakat.

Dalam penelitian ini permasalahan utamanya adalah mengenai apakah terdapat pengaruh dan bagaimana pengaruh pajak terhadap kesejahteraan masyarakat. Rumusan masalah penelitian secara lebih spesifik adalah: 1) Bagaimana pengaruh pajak terhadap tingkat kemiskinan di Indonesia? 2) Bagaimana pengaruh pajak terhadap tingkat pendapatan per kapita di Indonesia?

\section{Telaah Pustaka}

\section{Pajak dan Wajib Pajak}

\section{Pengertian Pajak}

Pajak adalah kontribusi wajib kepada negara yang terutang oleh orang pribadi atau badan yang bersifat memaksa berdasarkan Undang - Undang dengan tidak mendapatkan imbalan secara langsung dan digunakan untuk keperluan negara bagi sebesar-besarnya kemakmuran rakyat (Undang-Undang Nomor 28 Tahun 2007). Sedangkan menurut S. I. Djajaningrat dalam Resmi (2003), pajak merupakan kewajiban masyarakat yang diatur dan dapat dipaksakan menurut peraturan pemerintah untuk membayar ke kas negara yang akan digunakan untuk membiayai kesejahteraan masyarakat umum namun dengan tidak mendapatkan balas jasa secara langsung.

\section{Wajib Pajak}

Wajib Pajak adalah orang pribadi atau badan yang menurut ketentuan peraturan perundang-undangan perpajakan ditentukan untuk melakukan kewajiban perpajakan, termasuk pemungut pajak atau pemotong pajak tertentu. Seperti dikutip dari Waluyo (2010), wajib pajak merupakan orang pribadi atau badan yang menurut peraturan perundang-undangan perpajakan memiliki hak dan kewajiban baik sebagai pembayar maupun pemungut pajak.

\section{Pendapatan per Kapita}

Pendapatan per kapita dimaknai sebagai rata-rata pendapatan dari setiap penduduk suatu daerah. Pendapatan perkapita didapat dari pendapatan nasional suatu negara dibagi dengan jumlah penduduk suatu negara. Pendapatan per kapita dihitung dengan turut mempertimbangkan jumlah penduduk sehingga dapat digunakan untuk 
mengukur pendapatan nasional dan dapat digunakan untuk menggambarkan tingkat kesejahteraan masyarakat. Pendapatan per kapita mempunyai dua keunggulan. Pertama, GNP per kapita relatif mudah dihitung karena semua negara memiliki catatan tentang GNP atau GDP dan jumlah penduduk sehingga pendapatan per kapita bisa dihitung untuk semua negara. Kedua, ukuran ini cukup mewakili hakikat utama pembangunan, yaitu peningkatan kesejahteraan dan penghilangan kemiskinan (jika asumsi distribusi pendapatan terpenuhi). Pendapatan per kapita dihitung dari pendapatan nasional dibagi dengan jumlah penduduk untuk mengevaluasi pembangunan ekonomi (Chendrawan, 2017).

\section{Kemiskinan}

Kemiskinan merupakan keadaan saat kebutuhan dasar hidup seseorang (pangan, sandang, papan) tidak dapat dipenuhinya. Kemiskinan memiliki berbagai pendekatan. Beberapa lembaga yang menghitung kemiskinan di Indonesia adalah badan Pusat Statistik (BPS) dan Badan Koordinasi Keluarga Berencana Nasional (BKKBN).

\section{Garis Kemiskinan}

Garis kemiskinan merupakan ukuran yang dibuat oleh BPS sebagai batas pengelompokkan apakah suatu penduduk tergolong miskin atau tidak miskin. Garis kemiskinan dihitung berdasarkan pendekatan kebutuhan dasar, yaitu besarnya rupiah yang dibutuhkan untuk dapat memenuhi kebutuhan dasar minimum makanan (setara 2100 kalori/kapita/hari) dan non makanan seperti perumahan, kesehatan, pendidikan, angkutan pakaian dan barang/ jasa lainnya.

Garis Kemiskinan (GK) yang terdiri dari 2 komponen yaitu Garis Kemiskinan Makanan (GKM) dan Garis Kemiskinan Non Makanan (GKNM). Perhitungan garis kemiskinan dilakukan secara terpisah didaerah perkotaan dan pedesaan. (Statistik Indonesia, 2009).

1. Garis Kemiskinan Makanan merupakan nilai pengeluaran kebutuhan minimum makanan yang disetarakan dengan 2.100 kalori per kapita per hari.

2. Garis Kemiskinan Non Makanan adalah kebutuhan minimum untuk perumahan, sandang, pendidikan, kesehatan dan kebutuhan dasar lainnya.

$$
\mathbf{P}_{\alpha}=\frac{1}{\mathbf{n}} \sum_{i=1}^{\mathrm{q}}\left[\frac{\mathrm{z}-\mathbf{y i}}{\mathrm{z}}\right]^{\alpha}
$$

Dimana $A=0.1 .2$

$\mathrm{Z}=$ Garis kemiskinan

$\mathrm{y}_{1}=$ Rata-rata pengeluaran perkapita sebulan penduduk yang berada di bawah garis kemiskinan $(\mathrm{i}=1.2 .3 \ldots . . . \mathrm{q}) . \mathrm{yi}<\mathrm{q}$

$\mathrm{Q}=$ Banyaknya penduduk yang berada di bawag garis kemiskinan

$\mathrm{N}=$ Jumlah penduduk

Jika $\quad \mathrm{a}=0$ diperoleh Head Ccount Indeks $\left(\mathrm{P}_{0}\right)$

$\mathrm{a}=1$ diperoleh Poverty Gaps $\left(\mathrm{P}_{1}\right)$

$\mathrm{a}=2$ diperoleh Poverty Severity Index $\left(\mathrm{P}_{2}\right)$ 


\section{Metoda}

\section{Data dan Sumber Data}

Penelitian ini menggunakan data sekunder. Data sekunder adalah data yang bukan berasal langsung dari sumbernya atau bukan diperoleh langsung oleh peneliti (Marzuki, 2005). Data Sekunder dalam penelitian ini diperoleh dari Badan Pusat Statistik (BPS) Provinsi Jawa Tengah, serta publikasi lainnya.

\section{Metode Analisa}

Pengaruh pajak terhadap kesejahteraan dilihat melalui analisa regresi. Regresi merupakan metode untuk menentukan hubungan sebab-akibat antara variabel dengan variabel lain. Analisa regresi dilakukan dengan cara menentukan koefisien estimasi yang nantinya akan membentuk persamaan regresi. Analisis regresi mempelajari bentuk hubungan antara satu atau lebih variabel penyebab dengan satu variabel terkena (Irianto, 2004). Variabel penyebab biasa disebut variabel independen, yang pada umumnya digambarkan dalam sumbu X. Variabel terkena akibat dikenal sebagai variabel dependen, terikat atau variabel Y. Dalam penelitian ini, metode regresi yang digunakan untuk mengetahui pengaruh pajak terhadap tingkat kemiskinan dan pendapatan per kapita. Ada atau tidaknya pengaruh dilihat dari signifikansi F hitung dan thitung. Besaran dampak/pengaruh dicerminkan dari nilai elastisitasnya pada pendapatan per kapita dan angka kemiskinan.

Salah satu teknik analisis yang dapat digunakan untuk mengetahui hubungan 2 variabel kuantitatif adalah dengan melakukan uji korelasi. Hubungan 2 variabel disebabkan karena adanya hubungan sebab akibat. Apabila salah satu variabel mengalami perubahan kemudian diikuti dengan perubahan variabel lain baik dengan arah yang sama atau memiliki arah berlawanan maka dapat dikatakan dua variabel tersebut saling berkorelasi.

Kekuatan hubungan antara dua variabel dapat diukur dengan korelasi sederhana. Selain itu korelasi sederhana juga dapat digunakan untuk mengetahui hasil kuantitatif dari hubungan dua variabel tersebut. Bentuk hubungan dua variabel dapat berkorelasi linier positif atau linier negatif. Sedangkan kekuatan hubungan dua variabel dapat bersifat lemah, erat maupun tidak erat.

Koefisien korelasi digunakan untuk menentukan besarnya korelasi jika data yang digunakan berskala interval atau rasio. Sedangkan koefisien determinasi adalah bagian dari keragaman total variabel tak bebas y (variabel yang dipengaruhi atau dependen) yang dapat diterangkan atau diperhitungkan oleh keragaman variabel bebas $\mathrm{x}$ (variabel yang mempengaruhi atau independen). Untuk mengetahui seberapa besar hubungan variabel yang diuji sama dengan nol dapat dilakukan Uji Signifikansi Koefisien Korelasi. Apabila hasil pengujian menunjukkan bahwa hubungan variabel = nol maka dapat diartikan bahwa hubungan tersebut sangat lemah. Sedangkan pengujian yang menunjukkan hasil tidak sama dengan nol maka dapat diartikan hubungan antar variabel bersifat kuat (Santosa, 2004). 
Signifikansi F merupakan pengujian model fit data untuk mengetahui sejauh mana variabel X (independen) dapat mempengaruhi variabel dependen (Y). Model tidak dapat digunakan untuk memperkirakan pengaruh variabel independen terhadap variabel dependen atau disebut juga model tidak fit apabila nilai signifikansi F lebih tinggi dari 0,05. Namun apabila nilai signifikansi F lebih rendah dari 0,05 maka model dapat digunakan atau disebut model fit (Santosa, 2004).

Untuk menunjukkan pengaruh variabel independen terhadap variabel dependen dapat juga digunakan uji signifikansi t. Signifikansi t memiliki kriteria yaitu tingkat signifikansi $\alpha=5 \%(0,05)$, sehingga jika $p$ value $<0,05$ maka Ha diterima dan jika $p$ value $>$ 0,05 maka Ha ditolak (Santosa, 2004).

Uji $\mathrm{t}$ dikenal juga dengan uji parsial, yaitu untuk menguji bagaimana pengaruh masing-masing variabel bebas terhadap variabel terikat. Uji t dapat dilakukan dengan membandingkan t hitung dengan t tabel. Dasar pengambilan keputusan Uji t dalam analisis regresi yaitu :

Jika nilai $t$ hitung $>\mathrm{t}$ tabel maka ada pengaruh variabel bebas $(\mathrm{X})$ terhadap variabel terikat (Y) atau hipotesis diterima

Jika nilai $\mathrm{t}$ hitung $<\mathrm{t}$ tabel maka tidak ada pengaruh variabel bebas (X) terhadap variabel terikat (Y) atau hipotesis ditolak

Angka elastisitas adalah ukuran persentase perubahan pada satu variabel yang disebabkan oleh perubahan satu persen pada variabel lain. Elastisitas merupakan perubahan persentase variabel dependen yang ditimbulkan akibat adanya perubahan persentase variabel independen. Akibat dari perubahan variabel dan bagaimana hubungan sebab akibat dapat diamati berdasarkan elastisitas. Dalam regresi angka elastisitas dilihat dari perubahan persentase $Y$ akibat adanya perubahan persentase nilai X. Perubahan yang dimaksud bisa positif (searah) atau negatif (berbalik arah) sesuai tanda koefisien pada regresi. Konsep elastisitas digunakan untuk memperoleh ukuran kuantitatif respon suatu fungsi terhadap faktor yang mempengaruhi (Irianto, 2004). Jika persamaan $Y=b 0+b 1 X 1+b 2 X 2$, maka elastisitas jangka pendek dan jangka panjang dapat dirumuskan sebagai berikut: $\operatorname{ESR}=(\Delta \mathrm{Y} / \Delta \mathrm{X}) * \overline{\mathrm{X}} / \overline{\mathrm{Y}}$.

\section{Hasil dan Pembahasan}

\section{Pengaruh Pajak Terhadap Tingkat Kemiskinan di Indonesia}

Beberapa penelitian baik yang dilakukan di Indonesia maupun di luar negeri menunjukkan adanya hubungan antara pajak dan tingkat kemiskinan. Temuan dari penelitian-penelitian tersebut menunjukkan hasil yang bervariasi, dimana beberapa penelitian menyatakan besaran pajak mempercepat pengentasan kemiskinan seperti penelitian yang berjudul Dampak Kapasitas Fiskal terhadap Penurunan Kemiskinan: Suatu Analisis Simulasi Kebijakan (studi di 23 provinsi di Indonesia) yang dilakukan oleh Lisna, dkk (2013) serta penelitian yang dilakukan Ramadhan (2014) yang 
berjudul Pengaruh pajak, subsidi dan ZIS terhadap penurunan kemiskinan di Indonesia.

\section{Perkembangan Penerimaan Pajak dan Tingkat Kemiskinan di Indonesia}

Penerimaan dari sektor pajak merupakan sumber pendapatan terbesar bagi Negara Indonesia, dimana peruntukannya sebagaimana diamanatkan oleh konstitusi adalah dimanfaatkan untuk kemakmuran rakyat. Perkembangan penerimaan pajak tahun 2010 hingga 2019 sebagaimana ditampilkan pada Gambar 4.1 menunjukkan secara tren positif atau mengalami peningkatan, meskipun pada tahun-tahun tertentu mengalami fluktuasi sebagai dampak dari gejolak atau situasi ekonomi yang mengalami kontraksi. Disamping itu tingkat rata-rata pertumbuhan penerimaan pajak selama 10 tahun terakhir secara umum justru menurun. Tahun 2017 jumlah penerimaan pajak sedikit mengalami koreksi negatif. Hal ini mengingat pada tahun 2016 Pemerintah mengeluarkan kebijakan Tax Amnesty yang secara instan menggenjot penerimaan dari sektor pajak. Disamping itu tahun 2017 terjadi penurunan harga komoditas ekspor utama Indonesia (migas dan sawit) yang sedang mengalami penurunan di pasar dunia. Dampaknya adalah pajak dari kedua sektor andalan tersebut turut mengalami perlambatan. Namun pada tahun-tahun berikutnya relatif naik meskipun kembali ke titik semula tahun 2016.

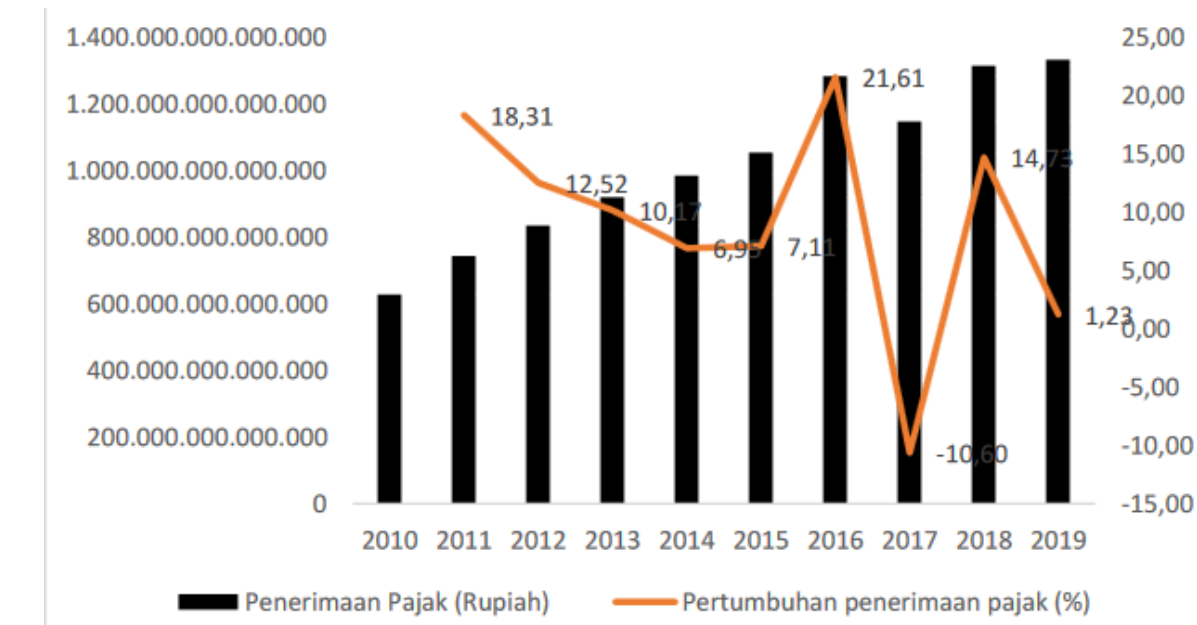

Gambar 1. Perkembangan Penerimaan Pajak (Rupiah) dan Pertumbuhan (\%) Indonesia Tahun 2010- 2019

Sumber: Data internal diolah, 2020 


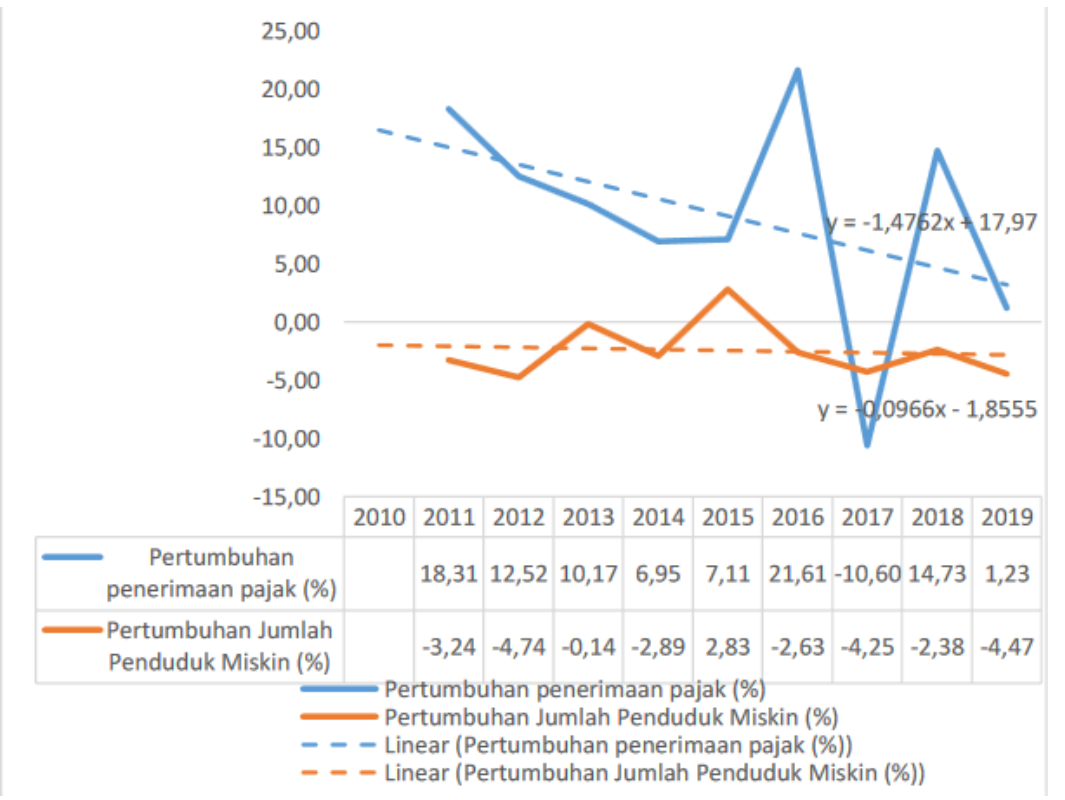

Gambar 2. Pertumbuhan Penerimaan Pajak dan Pertumbuhan Jumlah Penduduk Miskin (persen) Indonesia Tahun 2010-2019

Sumber: Data internal diolah, 2020

Gambar 2 menunjukkan fenomena yang cukup mengkhawatirkan bagi perekonomian nasional secara keseluruhan. Pertumbuhan penerimaan pajak dalam 10 tahun terakhir terus berfluktuasi dengan trend pertumbuhan yang menurun. Berbagai faktor penyebab memang dapat menjadi penjelas terjadinya kondisi ini, seperti situasi ekonomi global yang bergejolak, kondisi sosial politik yang beberapa waktu tengah menyelenggarakan pesta demokrasi (pemilu) maupun disebabkan faktorfaktor lainnya. Sementara penduduk miskin selalu mengalami penurunan dilihat dari angka pertumbuhan yang selalu negatif. Sekalipun demikian penurunan jumlah penduduk miskin masih tergolong stagnan dengan penurunan di bawah $5 \%$ per tahunnya.

\section{Korelasi dan Regresi Penerimaan Pajak terhadap Tingkat Kemiskinan di Indonesia}

Korelasi pada prinsipnya menggambarkan kekuatan hubungan antar variabel. Korelasi antara penerimaan pajak dan tingkat kemiskinan hendak menunjukkan kekuatan hubungan antara ke dua variabel tersebut. Nilai korelasi antara penerimaan pajak dan tingkat kemiskinan tersaji dalam Tabel 1 berikut: 
Tabel 1. Nilai Korelasi Penerimaan Pajak dan Tingkat Kemiskinan

\begin{tabular}{lc}
\hline No Variabel yang diuji & Nilai Korelasi \\
\hline 1. Korelasi Antara Penerimaan Pajak \\
dan Jumlah Penduduk Miskin \\
(data tahun 1996-2019) \\
2. Korelasi Antara Penerimaan Pajak \\
dan Persentase Penduduk Miskin \\
(data tahun 1996-2019) \\
3. Korelasi Antara Pertumbuhan \\
Penerimaan Pajak dan \\
Pertumbuhan Jumlah Penduduk \\
Miskin (data tahun 2010-2019)
\end{tabular}

Sumber : BPS, APBN berbagai tahun, diolah.

Keterangan :

Interpretasi Nilai Korelasi

0,00-0,199: sangat rendah/sangat lemah

0,20-0,399: rendah/lemah

$0,40-0,599$ : sedang

0,60-0,799: kuat

0,80-1,000: sangat kuat

Hubungan tingkat penerimaan pajak dengan beberapa parameter tingkat kesejahteraan yang dapat disimpulkan dalam penelitian ini adalah:

Penerimaan pajak memiliki hubungan negatif yang tergolong kuat terhadap jumlah penduduk miskin dan memiliki hubungan negatif yang tergolong sangat kuat terhadap persentase jumlah penduduk miskin. Hasil ini relatif mendukung beberapa hasil penelitian serupa yang dilakukan oleh peneliti-peneliti sebelumya di Indonesia. Meningkatnya jumlah penerimaan pajak, secara umum memberikan ruang gerak bagi Pemerintah untuk melakukan kebijakan-kebijakan yang bersifat social safety net yang bermuara pada peningkatan kesejahteraan masyarakat, serta kebijakankebijakan lainnya yang membuka kesempatan ruang kerja baru bagi para penganggur.

Pertumbuhan penerimaan pajak memiliki memiliki hubungan negatif, yang tergolong lemah terhadap laju pertumbuhan jumlah penduduk miskin. Kenaikan penerimaan pajak dari waktu ke waktu yang lebih rendah dibandingkan kenaikan jumlah penduduk miskin, diperkirakan merupakan penjelas yang paling rasional untuk menggambarkan temuan ini. Sebagaimana kita ketahui bahwa alokasi belanja negara relatif terbatas ruang lingkupnya. Sebagian besar dari anggaran belanja negara telah terserap untuk kegiatan belanja rutin. Sedangkan belanja-belanja yang bersifat produktif relatif memiliki porsi kecil dalam postur APBN kita. 
Tabel 2. Pengaruh Penerimaan Pajak Terhadap Jumlah Penduduk Miskin Indonesia Tahun 1996-2019

\begin{tabular}{lc}
\hline \multicolumn{1}{c}{ Indikator } & Nilai \\
\hline Multiple R & 0,689211 \\
R Square & 0,475012 \\
Adjusted R Square & 0,451149 \\
$\quad$ Significance F (alpha 5\%) & 0,00019537 \\
$\quad$ Stat (df 22) & \\
Intercept & 22,82514682 \\
Penerimaan Pajak (Rupiah) & $-4,46158$ \\
$\quad$ Coefficients & \\
Intercept & 39601840,47 \\
Penerimaan Pajak (Rupiah) & $-1,04534 \mathrm{E}-08$ \\
\hline
\end{tabular}

Sumber : BPS, APBN berbagai tahun, diolah.

Ada tidaknya pengaruh penerimaan pajak terhadap penurunan jumlah tingkat kemiskinan dapat diukur melalui hasil analisis regresi linier sederhana. Secara umum, dilihat dari angka signifikansi $\mathrm{F}$, hasil penelitian yang dapat ditarik dalam penelitian tentang pengaruh pajak terhadap tingkat kemiskinan ini adalah penerimaan pajak oleh negara memiliki pengaruh negatif dan signifikan secara model terhadap tingkat kemiskinan. Berbagai kebijakan pemerintah untuk mengalokasikan sumber-sumber pendapatan yang diperoleh bagi kesejahteraan masyarakat perlu mendapatkan dukungan partisipasi dari seluruh komponen masyarakat. Dukungan yang dimaksud bukan hanya dalam pemanfaatannya saja namun yang lebih penting adalah pengawasan penggunaannya agar tepat sasaran dan tepat tujuan, sehingga cita-cita kemakmuran bagi seluruh rakyat Indonesia dapat tercapai. Sementara apabila membandingkan uji t statistika dengan $t$ tabel pada degree of freedom 22 , didapati nilai $t$ hitung/ $t$ stat-variabel penerimaan pajak adalah $-4,46158$ sedangkan $t$ tabel senilai artinya t hitung $>\mathrm{t}$ tabel yang maknanya terdapat pengaruh penerimaan pajak terhadap penurunan kemiskinan secara signifikan.

Besaran pengaruh penerimaan pajak terhadap jumlah penduduk miskin dicerminkan dari angka koefisien penerimaan pajak. Angka koefisien penerimaan pajak hanya sebesar -1,04534E-08. Tanda negatif menunjukkan penerimaan pajak menurunkan jumlah penduduk miskin, namun apabila memperhatikan angka koefisiennya, penerimaan pajak hanya menurunkan jumlah penduduk miskin tidak lebih dari 0,0001 (hanya sebesar -1,04534E-08). Artinya setiap 1 satuan kenaikan pajak akan menurunkan penduduk miskin sejumlah 0,00000001 orang atau setiap Rp. 100.000.000 penerimaan pajak akan menurunkan jumlah penduduk miskin sebesar 1 orang. Nilai $\mathrm{R}^{2}$ sendiri hanya sebesar 0,475012 , hal ini berarti secara model, pengaruh penerimaan pajak terhadap penurunan jumlah penduduk miskin hanya berkisar $47 \%$.

\section{Pengaruh Pajak Terhadap Tingkat Pendapatan Per Kapita di Indonesia}

Berdasarkan hasil uji regresi sebagaimana tersaji dalam Tabel 3 dan 4 di bawah, pajak memiliki pengaruh positif terhadap pendapatan per kapita penduduk, meskipun pengaruhnya tidak signifikan. Pertumbuhan pendapatan per kapita yang merupakan hasil dari jumlah produk domestik bruto dibagi dengan jumlah angkatan kerja, diperkirakan lebih dipengaruhi oleh pertumbuhan ekonomi sebagai variabel 
prediktornya. Kemakmuran masyarakat akan tercapai dan dipengaruhi secara langsung oleh pertumbuhan ekonomi sebuah negara.

Pajak pada sisi lain, sebagaimana definisi dasarnya yang merupakan bentuk pungutan wajib yang dilakukan oleh negara pada warganya tanpa kewajiban kontraprestasi langsung, relative memiliki dampak yang tidak langsung terhadap pendapatan per kapita. Pada konteks Indonesia, dimana porsi anggaran untuk pembiayaan kegiatan yang bersifat rutin lebih besar dibandingkan dengan anggaran yang bersifat investasi, dampak terhadap pendapatan per kapita tentu akan lebih kecil.

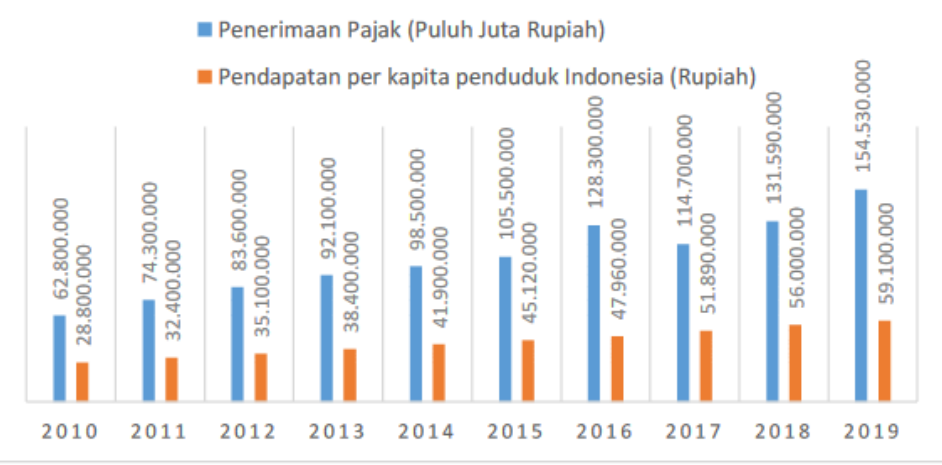

\section{Gambar 3. Penerimaan Pajak (Puluh Juta Rupiah) dan Pendapatan per Kapita (Rupiah) Indonesia Tahun 2010-2019}

Sumber : BPS, APBN berbagai tahun, diolah.

Gambar 3 di atas menyajikan perkembangan historis penerimaan pajak dan pendapatan perkapita untuk kurun waktu 2010-2019, terlihat perkembangan yang terjadi (berdasarkan angka absolut) relatif konstan dan seirama, terutama untuk pendapatan per kapita. Penerimaan pajak negara Indonesia dari tahun 2010 hingga 2016 terus mengalami peningkatan setiap tahun. Berbeda dengan penerimaan pajak yang sempat mengalami penurunan, pendapatan per kapita Indonesia terus mengalami peningkatan selama tahun 2010 hingga 2019. Rata-rata pertumbuhan pendapatan per kapita adalah sekitar $8 \%$ per tahun. 


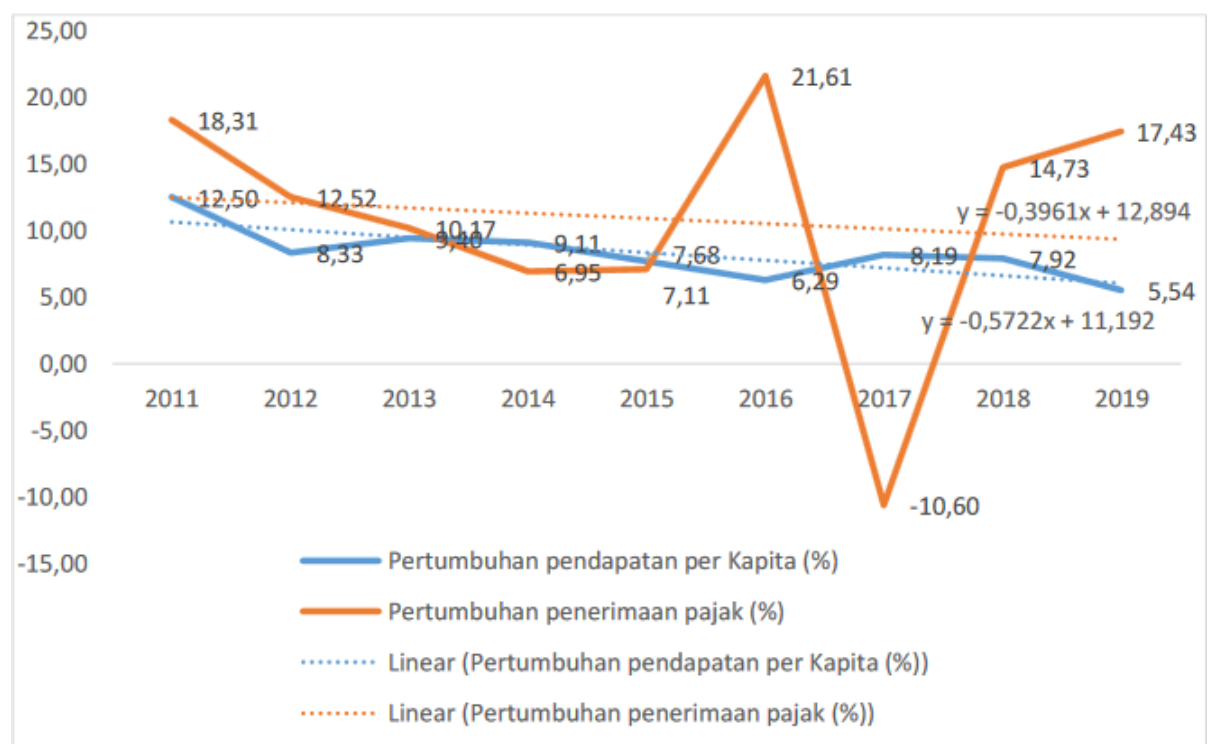

Gambar 4 Pertumbuhan Penerimaan Pajak dan Pertumbuhan Pendapatan per Kapita (persen) Indonesia Tahun 2010-2019

Sumber : BPS, APBN berbagai tahun, diolah

Perkembangan yang mengkhawatirkan justru terlihat dari pertumbuhan pendapatan per kapita berdasarkan persentase selama kurun waktu 2011-2019. Trend yang ada menunjukkan pendapatan per kapita masyarakat mengalami kecenderungan menurun. Hasil penelitian ini sekaligus mengkonfirmasi hasil penelitian serupa yang dilakukan oleh Vatavu, Lobont, Stefea dan Olariu (2019) yang mengambil sampel di negara-negara Eropa Timur. Salah satu temuan penelitian mereka adalah pada satu sisi pajak sedikit berpengaruh pada pertumbuhan ekonomi, namun tidak berpengaruh pada tingkat kesejahteraan masyarakat (yang salah satunya di-proxykan dengan pendapatan per kapita).

\section{Tabel 3. Nilai Korelasi Penerimaan Pajak dan Pendapatan per Kapita}

\begin{tabular}{clr}
\hline No & \multicolumn{1}{c}{ Variabel yang diuji } & Nilai Korelasi \\
\hline 1. & Korelasi Antara Penerimaan & 0,992 \\
& $\begin{array}{l}\text { Pajak dan Pendapatan perkapita } \\
\text { (data tahun 1996-2019) }\end{array}$ & \\
\hline
\end{tabular}

Sumber : BPS berbagai tahun, diolah.

Penerimaan pajak memiliki hubungan positif yang sangat kuat terhadap pendapatan per kapita. Hasil ini mendukung beberapa hasil penelitian serupa yang dilakukan oleh peneliti-peneliti sebelumya di Indonesia. Penerimaan pajak yang meningkat dapat mempengaruhi meningkatnya kesejahteraan masyarakat yang dapat diukur melalui salah satu indikator yaitu pendapatan per kapita. Dengan demikian apabila penerimaan pajak meningkat maka pendapatan per kapita juga ikut meningkat, sebaliknya apabila penerimaan pajak mengalami penurunan maka pendapatan per kapita juga dapat ikut menurun. 
Tabel 4. Pengaruh Penerimaan Pajak Terhadap Pendapatan per Kapita Indonesia Tahun 1995-2019

\begin{tabular}{l|c}
\hline \multicolumn{1}{c}{ Indikator } & Nilai \\
\hline Multiple R & 0,992047883 \\
R Square & 0,984159001 \\
Adjusted R Square & 0,983470262 \\
\hline \multicolumn{1}{c}{ Significance F (alpha 5\%) } & $3,28885 \mathrm{E}-22$ \\
\hline \multicolumn{1}{c}{ Stat (df 23) } & \\
Intercept & 0,148076541 \\
Penerimaan Pajak (Rupiah) & 37,80117275 \\
\hline \multicolumn{1}{c}{ Coefficients } & \\
Intercept & 115817,5694 \\
Penerimaan Pajak (Rupiah) & $4,07462 \mathrm{E}-08$ \\
\hline
\end{tabular}

Sumber : BPS, APBN berbagai tahun, diolah.

Ada tidaknya pengaruh penerimaan pajak terhadap pendapatan per kapita dapat diukur melalui hasil analisis regresi linier sederhana. Secara umum, dilihat dari angka signifikansi $\mathrm{F}$, hasil penelitian yang dapat ditarik dalam penelitian tentang pengaruh pajak terhadap pendapatan per kapita adalah penerimaan pajak memiliki pengaruh positif dan tidak signifikan secara model terhadap pendapatan per kapita. Sementara apabila membandingkan uji t statistika dengan t tabel pada degree of freedom 25, didapatkan nilai t hitung/ t stat- variabel penerimaan pajak adalah 37,80117275. Angka koefisien penerimaan pajak sebesar 4,07462E-08. Tanda positif menunjukkan penerimaan pajak meningkatkan pendapatan per kapita, apabila memperhatikan angka koefisiennya, penerimaan pajak meningkatkan pendapatan per kapita lebih dari 0,0001 (sebesar 4,07462E-08). Nilai $\mathrm{R}^{2}$ sendiri sebesar 0,984159001, hal ini berarti secara model, pengaruh penerimaan pajak terhadap pendapatan per kapita sekitar 98 persen. Temuan penelitian yang menunjukkan bahwa penerimaan pajak tidak berpengaruh terhadap pendapatan per kapita ini tentu menjadi sinyalemen yang perlu mendapat perhatian dari Pemerintah selaku pengelola pajak, sekaligus sebagai pihak yang mengelola "operasional" negara ini. Kebijakan-kebijakan yang langsung berdampak pada peningkatan kesejahteraan per kapita (yang pada akhirnya meningkatkan pendapatan per kapita) perlu ditempuh, terutama pada kondisi ekonomi yang sedang mengalami kontraksi dampak pandemi COVID-19.

\section{Simpulan}

\section{Simpulan}

Berdasarkan hasil analisis diperoleh hasil bahwa (1) perkembangan penerimaan pajak tahun 2010 hingga 2019 menunjukkan tren positif, meskipun pada tahun-tahun tertentu mengalami fluktuasi sebagai dampak dari gejolak atau situasi ekonomi yang mengalami kontraksi. Rata-rata pertumbuhan penerimaan pajak selama 10 tahun terakhir secara umum justru menurun. Hal tersebut dapat disebabkan berbagai faktor seperti situasi ekonomi global yang bergejolak, kondisi sosial politik dan lainlain. (2) Jumlah penduduk miskin selalu mengalami penurunan dengan angka pertumbuhan yang selalu negatif. Namun penurunan jumlah penduduk miskin masih tergolong stagnan dengan penurunan di bawah 5\% per tahunnya. (3) Pendapatan per kapita untuk kurun waktu 2010-2019 menunjukkan perkembangan yang relatif 
konstan dan seirama. Nilai pendapatan per kapita terus mengalami peningkatan selama tahun 2010 hingga 2019. Rata-rata pertumbuhan pendapatan per kapita adalah sekitar $8 \%$ per tahun. Sedangkan pertumbuhan pendapatan per kapita berdasarkan persentase selama kurun waktu 2011-2019 mengalami kecenderungan menurun. (4) Penerimaan pajak memiliki hubungan negatif yang tergolong kuat terhadap jumlah penduduk miskin dan memiliki hubungan negatif yang tergolong sangat kuat terhadap persentase jumlah penduduk miskin. (5) Pertumbuhan penerimaan pajak memiliki memiliki hubungan negatif, yang tergolong lemah terhadap laju pertumbuhan jumlah penduduk miskin. Pengaruh penerimaan pajak terhadap penurunan jumlah penduduk miskin berkisar 47 persen. (6) Pajak memiliki pengaruh positif terhadap pendapatan per kapita penduduk, meskipun pengaruhnya tidak signifikan. Penerimaan pajak memiliki hubungan positif yang sangat kuat terhadap pendapatan per kapita. Pengaruh penerimaan pajak terhadap pendapatan per kapita sekitar 98 persen.

\section{Saran}

Penelitian ini secara praktis memberikan implikasi kepada pemerintah untuk perlu meningkatkan upaya-upaya peningkatan kesadaran pajak masyarakat baik melalui sosialisasi ataupun pembinaan lainnya, hal ini mengingat pajak terbukti signifikan menurunkan angka kemiskinan. Selain itu berdasarkan hasil penelitian diketahui bahwa pengaruh pajak terhadap pendapatan per kapita tidak signifikan terjadi, hal ini dimungkinkan penerimaan pajak baru akan berdampak pada pendapatan per kapita dalam jangka waktu tertentu. Terkait hal ini pemerintah dapat mempercepat penyerapan anggaran yang terkait dengan penyediaan fasilitas publik agar masyarakat tetap dapat merasakan manfaat penerimaan pajak negara terhadap kesejahteraan melalui fasilitas publik. Berikutnya, pemerintah selaku pengelola pajak sekaligus sebagai pihak yang mengelola “operasional” negara juga perlu menerbitkan kebijakan-kebijakan yang langsung berdampak pada peningkatan kesejahteraan masyarakat sehingga pada akhirnya dapat menurunkan jumlah penduduk miskin dan meningkatkan pendapatan per kapita. 


\section{Daftar Pustaka}

Arini; Made Dwi Setyadhi Mustika. 2015. Pengaruh Pendapatan Asli Daerah dan Belanja Tidak Langsung terhadap Kemiskinan melalui Pertumbuhan Ekonomi di Provinsi Bali tahun 2007-2013. Jurnal Ekonomi Pembangunan Universitas Udayana Vol 4 (3): 11401163.

Brad, Anca Maria. 2012. The impact of tax policy on the welfare state. Conference Proceedings, Szeged, University of Szeged, Vol. ISBN 9: 182-195.

Chendrawan, Tony S. 2017. Sejarah Pertumbuhan Ekonomi. Tirtayasa Ekonomika Vol. 12, No 1, April 2017

Fitriah, Elis Anisah et al. 2019. Faktor-Faktor Psikologis sebagai Determinan Kepatuhan Pajak: Studi Eksplorasi pada Wajib Pajak. PSYMPATHIC : Jurnal Ilmiah Psikologi, Volume 6, Nomor 1, 2019: 99-110

Irianto, Agus. 2004. Statistik Konsep Dasar \& Aplikasinya. Jakarta : Kencana

Kementerian Keuangan. 2019. APBN 2019. Diakses dari : www.kemenkeu.go.id

Lisna, Vera; Bonar M. Sinaga; Muhammad Firdaus dan Slamet Sutomo. 2013. Dampak Kapasitas Fiskal terhadap Penurunan Kemiskinan:Suatu Analisis Simulasi Kebijakan. Jurnal Ekonomi dan Pembangunan Indonesia Vol 14 (1): 1-26.

Mardiasmo. 2016. Perpajakan Edisi Revisi 2016. Yogyakarta : Andi.

Marzuki. 2005. Metodologi Riset. Yogyakarta : Ekonisia

Muana, Nanga. 2001. Makro Ekonomi, Masalah dan Kebijakan. Jakarta : PT. Raja Grafindo Persada.

Ramadhan, Hikhmatiar, Tatik Mariyanti. 2014. Pengaruh Pajak, Subsidi dan ZIS terhadap Penurunan Kemiskinan di Indonesia. Media Ekonomi Vol 22 (2): 123-132.

Resmi, Siti. 2003. Perpajakan : Teori \& Kasus. Jakarta : Salemba Empat

Santosa, Singgih. 2004. SPSS Statistik Multivariat. Jakarta : Elex Media Komputindo

Sulastyawati, Dwi. 2014. Hukum Pajak dan Implementasinya Bagi Kesejahteraan Rakyat. Diakses dari : https://www.academia.edu/9989886

Undang-Undang Nomor 28 Tahun 2007 Tentang Ketentuan Umum dan Tata Cara Perpajakan

Vatavu, Sorana; Oana-Ramona Lobont; Petru Stefa dan Daniel Brindescu-Olariu. 2019. How Taxes Relate to Potential Welfare Gain and Appreciable Economic Growth. Sustainability Journal Vol 11: 1-16.

Waluyo. 2010. Perpajakan Indonesia. Jakarta : Salemba Empat 